\title{
Gabon Wood Industry and Chinese Companies Activities
}

\author{
Aba'a Ondo Yoan', Yongji Xue1, Mesmin Junior Mbyamm Kiki²* \\ ${ }^{1}$ School of Economics and Management, Beijing Forestry University, Beijing, China \\ ${ }^{2}$ School of Computer Science, Beijing University of Technology, Beijing, China \\ Email: yoanabaa93@gmail.com, *mbyamm10@ya hoos.fr
}

How to cite this paper: Yoan, A.O., Xue, Y.J. and Mbyamm Kiki, M.J. (2018) Gabon Wood Industry and Chinese Companies Activities. Open Access Library Journal, 5: e4553.

https://doi.org/10.4236/oalib.1104553

Received: March 29, 2018

Accepted: May 28, 2018

Published: May 31, 2018

Copyright (c) 2018 by authors and Open Access Library Inc.

This work is licensed under the Creative Commons Attribution International License (CC BY 4.0).

http://creativecommons.org/licenses/by/4.0/

\begin{abstract}
The investments made by the Asian companies, in particular, the Chinese companies in the forestry sector in Gabon over the past fifteen years, appear each day more and more important. These companies are indeed specialized in the buyout of multinationals, permit or to Gabonese capital and companies in the business of "farming" with forest concessions of national operators. In this paper, we are going to analyze the point of the level of their contribution in the sector Gabonese wood by segment business (operations and forest management, timber processing and export and marketing of logs and derivatives) and the degree of their involvement in the implementation of the laws and regulations (code Forester, labor code and code of the environment) in force in Gabon. It is clear that Chinese-owned companies have become major players in the industry Gabonese wood. Thus, they are the first operators of the Gabonese wood with a total area of 2.84 .483 ha or $25.11 \%$ of the forest area operating in that country; in addition, they are, with their established wood industries $15.29 \%$ in Gabon, the third group of operators in this segment of activity and also are the top exporters of Gabonese wood with an annual average of logs over 1 million $\mathrm{m}^{3}$ (representing more than $70 \%$ of the wood Gabonese exported). However, this leadership is characterized by large gaps and weaknesses in the implementation of the Gabonese regulation.
\end{abstract}

\section{Subject Areas}

Forestry Exploitation, Business Finance and Investment, Development Economics, Economic System

\section{Keywords}

Gabon, Wood Industry, China Investment 


\section{Introduction}

The policy (Growth and Reduction of our forest) of the Gabonese Republic was to promote rational and sustainable management of forests. This decision is supported by many partners, the most important of which is the European commission, which helps to build and improve over time a set of regulations and of tools that enhance the control of the future production for export and monitoring of the area. Since 2003, the European Union has reacted to these problems in the framework of the FLEGT process and, in the light of this, proposes a plan of action for the countries producers of tropical forests in their efforts to improve their forest policies and promote public welfare [1]. The FLEGT process is the European Commission's reaction to the scourge of illegal logging and the timber trade, which is to say. This process is today the world stage of the introduction, starting with Africa and Asia. The Gabonese Republic, taking into account the economic and ecological problems of the forest and the forest industry sector, adheres to the principles of the FLEGT process, to be better prepared for the European market of tomorrow. The year 2008, formally asked the European Union in the training process, as well as the appointment of a contact group in the forestry administration, has distinguished desire responsible for the FLEGT process in Gabon to negotiate. The country is preparing for a voluntary partnership agreement (VPA) with the European Commission to negotiate, consolidate national policies and ensure that both sides of the export forest products export to Europe, as approved by the FLEGT, approved the system of control of the legality and the traceability [2].

As a reminder of our days, Ghana, Congo and Cameroon are the three African countries that have signed the Volunteer with the EU partnership agreements. In the view of many observers, the FLEGT and one of its technical instruments that is the partnership agreement Volunteer (VPA) have many advantages to position itself as an effective tool to fight against exploitation illegal in the forest sector. One of the criticisms that had been made to the origin of the FLEGT Action Plan was that its regulation may encourage the implementation of a two-tier, legal to export system Europe and the rest to China or other markets [3]. Now it turns out that the first countries (Ghana, Congo, Cameroon) who have concluded an agreement, conscious of their image but also their industry wood, decided to apply the system of verification of legality established under the agreement to all their exports, whether to the EU, China or other countries. It should also be noted that, during the various consultations that China has regularly with other importing countries partners, this country has made clear its willingness to join any dynamic to strengthen the rule of law [4]. One year ago, the Chinese Administration issued guidelines for Chinese Entrepreneurs in the sector wood to foreign countries, including in Africa. The same representatives of China regularly reported their bad knowledge of the context of the country of origin of the Woods coming into China. Moreover, under the FLEGT VPAS, IUCN in his capacity as facilitator of the dialogue between stake- 
holders at this process in Gabon and other countries of the basin of the Congo (Cameroon and Congo who have already signed such agreements), would want to put at the disposal of all these actors some clear that represents China in the sector wood to the Gabon [5]. The results of this study should facilitate the promotion of these guidelines.

\section{Methodological Approach}

\subsection{Setting of the Research}

The objective of this research is to understand the role and the impact of the activity of the Chinese companies in the sector wood in Gabon. More specifically to:

- A State of affairs of Chinese-owned forest companies;

- An analysis of the share of the exploitation, processing and Chinese companies lumber exports compared to the rest of the operators;

- An assessment of the implementation, by Chinese operators, the provisions of law 16/01 to December 312001 on forest code in the Gabonese Republic in general and specifically their commitment in forest management and certification;

- A prospective analysis of the future development of the activity of the Chinese operators in Gabon. Thus the State of the forest companies to Chinese capital (economic operators in the forestry sectors and timber industry whose funding is provided in whole or in part by Chinese private funds or State) consisted in the development of the detailed and updated monograph of these companies operating in Gabon. In this perspective, through direct observations made from the surveys and interviews with the companies China and indirect administration and other partners, the following information was collected:

- title of operation;

- Area of intervention and exploited surface.

- Acquisition of additional area needs;

- Capital and turnover;

- current operational capabilities:

- equipment used including its origin;

- staff used (nationality and level of training);

- Volume of wood exploited, processed and exported;

- Type of gasoline marketed, use and destination;

- level of intervention following the industry segments wood;

- processing capacity and industrial development project;

The analysis of the weight of Chinese interests in the sector wood has by comparison to other operators countries (Gabon, France, Italy, etc.) that operate in Gabon. On this aspect, a comparison of the elements below will be made:

- Areas assigned;

- Volume of wood produced;

- Volume of exported wood; 
- Level and quality of investment;

- Turnover.

The assessment of the implementation by Chinese operators, the provisions of law 16/01 in general and particularly their involvement in forest management will be essentially based on the analysis of the implementation of the Conventions development of Transformation.

Operation or land use plans. As for their commitment in the certification, it was estimated through the number of certificates achieved or are being obtained by these companies. Finally, the future development of the activity of the Chinese operators in Gabon resulted from growth prospects in the wood industry, medium and long term announced by the latter during the interviews.

\subsection{Processing and Data Analyzing}

Treatment and analysis of the quantitative data collected from Chinese operators and other actors working with these required the use of descriptive statistics. As for qualitative data, they have been analyzed according to an approach of intersection of the diverse views collected from Department of Forest Economy, Waters, Fisheries and Aquaculture, or World Resources Institute, or different Gabonese companies, Chinese or many others.

\section{General Overview of forestry in Gabon}

The Gabonese forest covers 22 million hectares of which 14 million of the permanent area of the State and 8 million hectares rural area (areas for community forests, hunting and fishing areas, etc.) [6]. The field standing of the State is divided into 10 million hectares of production of softwood lumber and 4 million hectares of forest areas protected. Inventories of development drivers in the 1990s revealed the presence in the Gabonese of forest nearly 350 potentially exploitable species including a 60 only subject to levy. It comes including of Ozigo Okoumé and other so-called "various wood" species [7]. Supply of okoumé (gasoline which has excellent skills in unwinding to the best quality plywood) was evaluated in 1995 to $130 \mathrm{million} / \mathrm{m}^{3}$. The total potential of timber is about $400 \mathrm{million} / \mathrm{m}^{3}$, of which $1 / 3$ consists of Okoumé, and so-called essences 'various wood' represent the rest [8]. Wildlife does not count less than 130 species of mammals including 19 primates with significant populations typical of the forests of Central Africa: apes (chimpanzees and gorillas), Bongos or elephants (with approximately) (60,000 individuals) [9]. In terms of Government policy, law 01/016 of 31 December 2001 on the forest Code in the Republic Gabonese dedicated the forest management, just as the industrialization of the sector wood, the conservation of the biodiversity and the effective involvement of the locals, as the major axes of development in the sector. Due to the downward trend in revenues from oil exploitation, the Government expected sees the sector forest increase and optimize its contribution in the production of the country's wealth. This contribution, estimated currently at $4.5 \%$ of GDP should be in- 
creased to 10\% in 2012 (according to the forest Code of 2001). It should be noted that for the year 2007, the sector wood has experienced strong growth of its added value. This one has increased by $22 \%$, from 190.9 billion CFAF in 2006 to 232.9 billion in 2007. He that's the first results of management policy forest to resource development and sustainable through the actions initiated since the 1990s with the multifaceted contributions.

The outline of this new policy was included in the letter of policy of the Minister in 2002 [10]. It is question: to protect the environment and improve its condition, maintain and rationally manage forest resources, to encourage the production of new information about the Gabonese forest, Exploit the forest products according to management plans, highlight economic, and natural resources by developing the sector wood, in organizing activities in fishing, tourism around protected areas as we can see in Table 1. Because the achievement of these objectives requires the mobilization of regulatory, financial and very important human resources, the following instruments have been identified for the implementation of this policy [11]. This is the adoption of the new forest Code and implementation including the obligation to develop national standards of planning production forests, the promotion of a forest tax incentives in favor of industrialization, the development of commercialization of the products, the development of education and awareness of the public on environmental and forestry issues, the development of training and the research, the participation of nationals in the process of development of the rural areas, strengthening of national institutions.

The areas dedicated to exploitation in Table 1 represent about 1,300,000 hectares, to add production forests Permanent vocation, or 832,000 hectares. Divided into six distinct massifs, for which management plans already existed. It comes including: 1 of the massif of the estuary South to 263,100 hectares, very rich in okoumé, was the subject of a development, part of which has been attributed to the IFK society; of the massif Remboue for 185,000 hectares, widely exploited and poor to reserve; of the massif of the company for 106,300 hectares, integrating the plantations and having been development, was awarded to the company Chinese Hua Jia; of the massif of the Mvoum for 104,000 hectares including the forest reserves of the no koulounga and of the top-Komo. This strategic land use plan will be consolidated in law 016/01 of December 31, 2001 wearing Forest Code in Gabonese Republic. Figure 1 contains the general architecture of the zoning of the Gabonese forest sector.

\section{Regulation Framework and Normative}

\subsection{Regulation Framework}

The forest Code, based on the experiences and the knowledge capitalized projects drivers run in the 1990s, is one the most spectacular advances in the field forest in Gabon [12]. It was adopted by the Parliament of the Gabon by the Act No. 016/2001 of 31 December 2001 and promulgated by the President of the 
Table 1. Forest organization.

\begin{tabular}{ccc}
\hline Type & Vocation & Area (Ha) \\
\hline \multirow{2}{*}{ State Forests Classified } & Existing Rational exploitation of Wildlife areas & 832,000 \\
& Areas of Proposed Protection & 934,000 \\
& Agricultural Areas & 234,000 \\
Protected Forests & Industrial Crops & $1,493,000$ \\
& Forest Operating Areas & 28,000 \\
Others & Oil sites, Urban areas, Landmarks & $1,295,000$ \\
Total & & 151,000 \\
& & $4,967,000$ \\
\hline
\end{tabular}

Source: Christy et al.

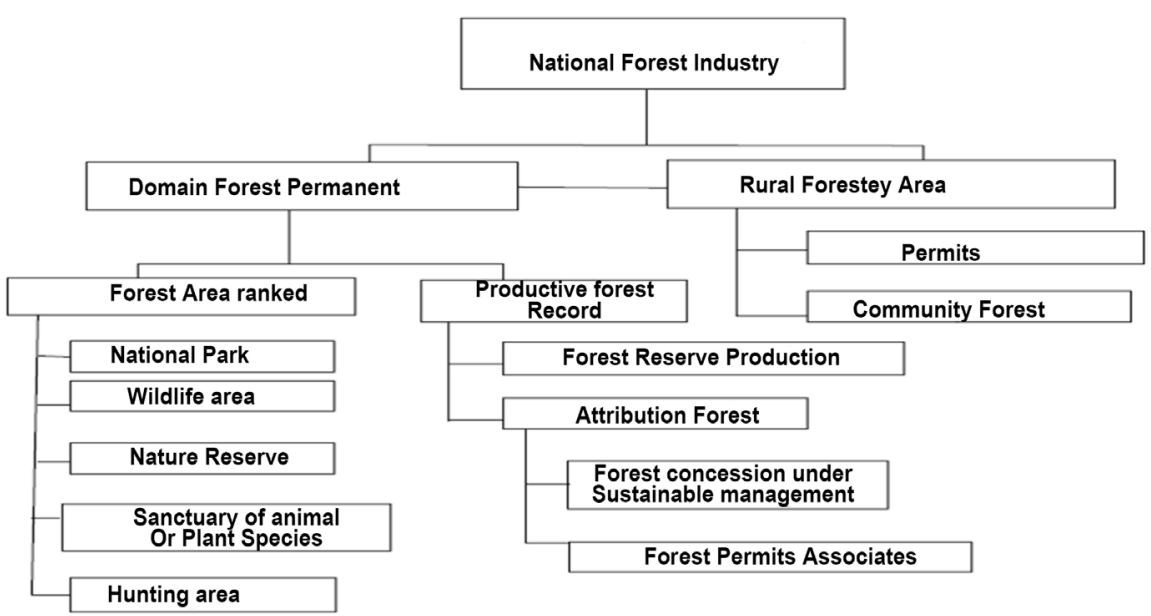

Figure 1. Gabonese forest sector zoning. Source: Interpretation of law 016/01 about the forest code of Gabon republic.

Republic, head of the State [13]. The overall objective of this policy is to increase the GDP in this sector by $4.5 \%$ currently to $10 \%$ in 2012 by promoting, among other two axes headlights:

- The development of the complex of production forests of the permanent area of the State (14 million hectares) by the incentive to certification granted con-cessions;

- And increased industrialization of production wood. Furthermore, it should be noted that the major innovations of the forest Code, in terms of sustainable management are:

- The institutionalization of the process of creation and management of com-munity forests by people beneficiaries in order to combat poverty in rural areas;

- The principle of establishing a fund to support national efforts National forest (FFN) development and especially artificial forest regeneration. Finally, an ordinance (No. 011/PR/2008 of 25 July 2008) amending and supplementing certain provisions of the Code forester was taken, particularly regarding commercialization of Okoumé and ozigo monopoly by the National Society 
of the woods of Gabon, mode of forest licensing, terms of sale, of transmission and transfer of associated forest licenses [14] (Figure 2).

\subsection{Forest Taxation}

Taxation has been reviewed by the Administration in charge of the forests in 2000 in order to adapt to the new context. This last is characterized by the pre-eminence of the concepts of forest management and further industrialization wood industry [15]. So taxes area, slaughter and the rights fees and output have been revised upward to an increase the tax yield of the 2003 to 2008 period. It went from 2 billion to 12 billion in 2007.

\subsection{Allocation and Management of Forest Resources}

In order to allow operators and forest companies to have a guarantee of supply of logs long-term, the allocation of forest concessions is in Gabon by tender since 2008. It is now based on two (2) types of permit forest: forest concessions under sustainable management whose per unit area varies between 50,000 and 200,000 hectares and associated forest permits (PFA) a less or equal to 50,000 hectares [16]. However, in order to avoid that this system leads to the eviction of the Gabonese of the forest, the adopted strategy is to book $40 \%$ of the forest of the area standing at nationals [17]. These permits are fifty (50) feet of hammered
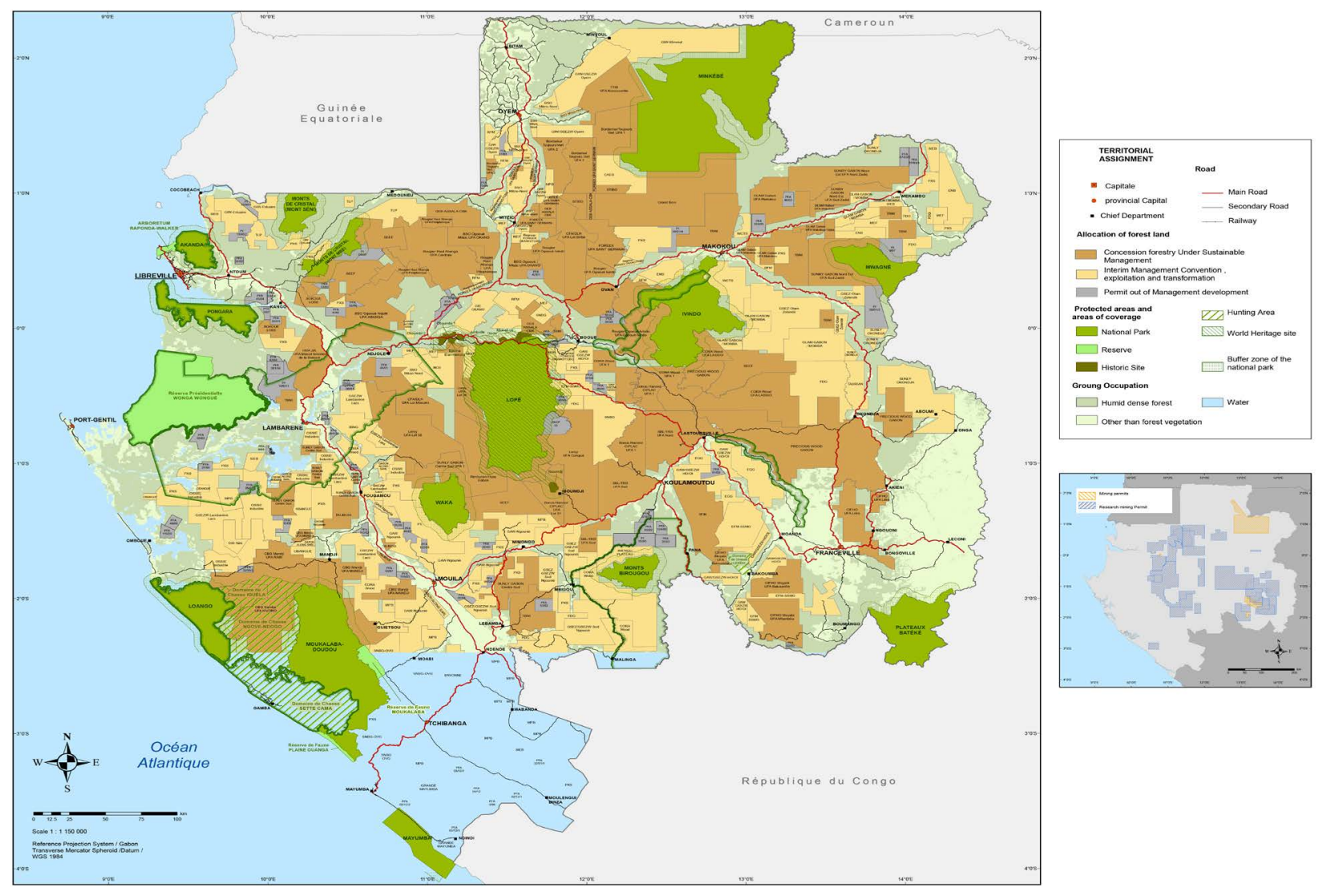

Figure 2. Assignment of forestry. Source: Directorate for development of tiber industries and trade. 
exploitable trees and are awarded in areas previously materialized by the administration of waters and forests.

\section{Forest and Tiber industry in Gabon}

The sector Gabonese wood until the 1990s was dominated mainly by logging and the export logs. Eleven years later, the Government redefined its forestry policy with forest management and processing local wood as major axes [18]. To date,

- 6,958,829 hectares of forest are registered in the process of development through the production of plans planning and programs of industrialization by some operators in the sector wood a part, signed interim agreements development-operation-transformation (CPAET) by some holders of permits on the other hand;

- $3,419,475$ hectares have been validated by the administration forest, constituting thus management plans concessions forest sustainable management (CFADS); regarding the first transformation of the wood, the rate fell from $35 \%$ to $100 \%$ on decision Government of November 4, 2009. In the short term, this measure will especially lead the closure of many companies not in good standing compared to the forestry provisions in force (permit undeveloped, insufficient transformation rate) with the collateral is related (dismissal of certain) staff, loss of income by the State) [19]. In the medium and long term, the new measure processing in situ of the entire production of the Gabonese wood will have many effects beneficial grace to the added value that the local processing of all wood will lead to:

- The relocation of foreign companies to the Gabon. This will allow this country to play a role prominent among the regional actors and International engaged in the production and the marketing of timber;

- The effect of leverage for other sectors of activities;

- The creation and promotion of other trades of the forest-based industry (product marketing, innovation) and designer, industrial manufacturing...);

- The effect of the development of the industrial activity on the entire territory;

- The redeployment of production with an exponential increase in jobs in the segment industrial;

- Diversification of the production of softwood lumber of high value-added (2nd and 3rd transformation) with effect induced increase the income of the Gabonese State. In addition to the benefits mentioned so high, this strategy should allow the Gabonese State to be eligible for the REDD program (Reduction of Emissions from Deforestation and Degradation) that support financially the country working in the reduction of deforestation and carbon sequestration initiatives.

\section{Chinese Company in Wood industry in Gabon}

Chinese-owned companies, mainly funded by the Chinese Government because 
of the large wood needs of this country, formed in Gabon since 15 years according to the redemption of multinationals, permit or Gabon in difficulties-owned companies and the activity of the "rent" from the concession of National [20]. One of the most significant examples is the purchase in April 2009 Leroy Gabon (Plyrosol) group by Honest Timber a Chinese firm (Belligoli, 2010). To date, logging in Gabon is carried out on a total area of 11,325,667 hectares distributed over 701 valid permits awarded to 60 of economic operators for an annual production of logs which varies 3 to $3.5 \mathrm{million} / \mathrm{m}^{3}$ [21]. In this panorama, Chinese-owned companies are holders of a total area of 2,844,813 ha representative $25,11 \%$ of forest area operated in Gabon. Like other forest companies installed in Gabon. Chinese companies have also specialized in the operation of lighthouses in this country species that are the okoumé, the Woods and Ozigo [22]. Taking into account of the annual production of all permits Gabon and the ratio of forest owned by the Chinese, he Spring, by extrapolation, that these operators have a quarter of the Gabonese logs annual production between 750 and 850,000 $\mathrm{m}^{3}$. Table 2 shows the man companies involved in logging.

\section{Gabon Forestry Management and Chinese Companies Benefits}

Forest management remains the flagship segment of the Gabonese timber industry with 10,324,113 hectares of forest under contract in the planning process, of which $6,958,829$ hectares are the subject of provisional development Exploitation-Transformation (CPAET) and 3,419,475 ha are underdeveloped Forest Concessions Sustainable (CFAD) [23]. Of these, 1.8 million ha are already FSC certified as we can see in Table 3. Chinese-owned companies, for their part, seem to be actively involved in this process with 818,932 ha of forest under development is a ratio of $23.94 \%$ of Gabonese managed forests [24]. This contribution is actually the fact of the commitment of 3 major companies Leroy Gabon, the Industrial Company Forest of Koulamoutou (SFIK) and the Huajia group. The first, originally European, has been engaged for a long time, the second had its plan approved since 2009 and the third has, by convention, acquired the Bokoué reserve (Kango) which has management plan carried out by the Forest Administration under the ITTO project since 1996 as we can see in Table 3.

\section{Gabon Wood Processing and Chinese Companies Interests}

Wood processing in Gabon, characterized by the primary processing industry (sawing, and peeling) and to a lesser extent that of the second (plywood panels and planed sawing) and third transformation (joinery and cabinet making), constitutes one of the major axes of diversification of the Gabonese economy. Promoted by Forest Code 016/01 of 31 December 2001 [25]. For the year 2009, wood processing, any business segment combined, required $862,346 \mathrm{~m}^{3}$ of logs for a production of $463,397 \mathrm{~m}^{3}$ of processed wood, representing an overall yield of $54 \%$. These numbers testify to the level acceptable quality of products 
Table 2. Main companies involved in logging.

\begin{tabular}{cccccc}
\hline Enterprise & $\begin{array}{c}\text { Capital (millions } \\
\text { of XAF) }\end{array}$ & $\begin{array}{c}\text { Number } \\
\text { Of Permits }\end{array}$ & $\begin{array}{c}\text { Total } \\
\text { Area (ha) }\end{array}$ & Location & People \\
$\begin{array}{c}\text { Honest Timber } \\
\text { Gabon (HTG) }\end{array}$ & ND & 28 & 409,107 & $\begin{array}{c}\text { Estuaire } \\
\text { Ngounie } \\
\text { Nyanga }\end{array}$ & $\begin{array}{c}\text { 200 Gabonese } \\
50 \text { Chinese }\end{array}$ \\
Sunry-Gabon & 10 & 2 & 330,196 & $\begin{array}{c}\text { Ogoue-Invido } \\
\text { Oaut-Ogooue }\end{array}$ & ND \\
$\begin{array}{c}\text { Sunly-Gabon } \\
\begin{array}{c}\text { Transport Bois } \\
\text { Negoce }\end{array}\end{array}$ & 10 & 16 & 695,233 & $\begin{array}{c}\text { Ogooue-Ivindo } \\
\text { Moyen Ogooue }\end{array}$ & ND \\
$\begin{array}{c}\text { International } \\
\text { Hua Jia }\end{array}$ & ND & 24 & 438,386 & Ogooue-Ivindo & ND \\
$\begin{array}{c}\text { Leroy Gabon } \\
\text { KFIC: Koulamoutou } \\
\text { forestry-Industrial }\end{array}$ & ND & 1 & 108,000 & Estuaire & ND \\
$\begin{array}{c}\text { FIL: Forest Industry } \\
\text { of Lambarene }\end{array}$ & ND & 6 & 576,642 & Ogooue & 500 \\
\hline
\end{tabular}

Source: Directorate for development of timber industries and trade.

Table 3. Concessions with respect to the forest management process in Gabon.

\begin{tabular}{|c|c|c|c|}
\hline & Managed forest Concessions & Assigned Area & Observations \\
\hline A & Total area of manages forests & $3,419,475$ & $1,837,620$ ha are FSC Certified \\
\hline B & $\begin{array}{c}\text { Total area of forest under } \\
\text { planning }\end{array}$ & $4,271,196$ & $\begin{array}{c}\text { Include Validated development } \\
\text { plan and in the course of } \\
\text { validation }\end{array}$ \\
\hline C & Total CPAET area & $6,052,917$ & $\begin{array}{l}2 \text { Includes signed and Pending } \\
\text { CPAETs }\end{array}$ \\
\hline $\mathrm{D}$ & $\begin{array}{c}\text { Total area of forests engaged } \\
\text { in the process }\end{array}$ & 10,324113 & 1 \\
\hline
\end{tabular}

Source: Directorate for development of timber industries and trade.

processed by the Gabonese industry, including veneered and plywood products show the highest yields (64\% and $77 \%$ respectively). Chinese-owned companies rank third in the group of Gabonese wood processors with $15.29 \%$ of industrial capacity behind the French $(28.21 \%)$ and the Gabonese $(22.35 \%)$ as we can see in Table 4. They are the owners of an estimated $96,181 \mathrm{~m}^{3}$ of wood production, or $20.7 \%$ of the volume of wood processed in this country as we can see in Table 4. This volume represents only a marginal part (11\%) of their theoretical annual $\log$ production estimated between 750 to $850,000 \mathrm{~m}^{3}$ In this sense, the COFCO group, represented by subsidiaries Sunly-Gabon and SAFOR Industries, with a cumulative volume of logs (Okoumé and Azobé) of 34,185.68 $\mathrm{m}^{3}$, transformed in 2009 less than half of this volume of $16,399.58 \mathrm{~m}^{3}$ and obtained a milled production of $8796.52 \mathrm{~m}^{3}$ of which less than $5 \%$ was sold locally. This result confirms the fact that Chinese companies export almost all timber harvested and 
Table 4. Concessions with respect to the forest management process in Gabon.

\begin{tabular}{ccccc}
\hline Interests & Sawing & Peeling & Total & Total (\%) \\
\hline French & 19 & 5 & 24 & 28.24 \\
Gabonese & 17 & 2 & 19 & 22.35 \\
Chinese & 8 & 5 & 13 & 15.29 \\
Malaysians & 7 & 1 & 8 & 9.41 \\
Lebanese & 7 & 0 & 7 & 8.24 \\
Other & 3 & 0 & 3 & 3.53 \\
Moroccans & 1 & 1 & 2 & 2.35 \\
Italians & 1 & 1 & 2 & 2.35 \\
Portuguese & 1 & 0 & 1 & 1.8 \\
Spanish & 1 & 0 & 1 & 1.8 \\
Indians & 1 & 0 & 1 & 1.8 \\
Ivoirians & 1 & 0 & 1 & 1.8 \\
Switzerland & 1 & 0 & 1 & 1.8 \\
Cameroonians & 1 & 0 & 85 & 1.8 \\
Total & 70 & 15 & & 100 \\
\hline
\end{tabular}

Source: Directorate for development of timber industries and trade.

processed [26]. This means that, they participate weakly in the further industrialization of Gabonese timber and in the rise of the Gabonese economy. In response to this state of affairs, and in view of the decision of the Gabonese State to ban the export of As of May $15^{\text {th }}$ 2010, the numerous companies with Chinese capital surveyed said, plan the increase of their level of wood processing, notably through the acquisition of processing equipment more efficiently [27]. Thus, the company Sunly-Gabon confided, that in addition to the current industrial capacities, it planned the construction of a peeling factory and sawmill at its site in Lambaréné (Moyen Ogooué). In terms of the use of human resources, it is noted to the credit of the industrialists surveyed that comparatively logging segment, the number of Gabonese employees is significantly higher compared to the Chinese and to other nationalities. This is particularly the case of HTG, Emirates and Hua Jia who participate in the policy of full employment of Gabon as we can see in Table 5.

\section{Prospective Analysis the Evolution of Activities Evolution of Chinese Companies}

In light of the information preceding the weight and impact of Chinese companies in operation, development, transformation and export of Gabonese wood, and in the light of the recent measures Government related to the total ban on exports of logs of This country, the likely evolution of the activities of these operators could be: The shutdown of their activities; the continuation and the 
Table 5. Chinese companies engaged in forest procession.

\begin{tabular}{|c|c|c|c|c|c|c|}
\hline Companies & Activity & Location & $\begin{array}{l}\text { Actual Annual } \\
\text { Capacity (M3) }\end{array}$ & Month & Staff & Observation \\
\hline HTG & Peeling & Kango & 18,000 & 1500 & ND & $\begin{array}{c}\text { Creation early } \\
2010\end{array}$ \\
\hline $\begin{array}{l}\text { ShengYang } \\
\text { Inter. Gabon }\end{array}$ & Peeling & Booue & 10,000 & 600 & ND & $\begin{array}{c}\text { Creation early } \\
2010\end{array}$ \\
\hline Sunly Gabon & Peeling & Lambarene & 14,400 & 7000 & ND & $\begin{array}{c}\text { Creation early } \\
2010\end{array}$ \\
\hline Along SARL & Sawing & Owendo & 12000 & 1000 & $\begin{array}{c}90 \text { People: } 60 \\
\text { Gabonese and } 9 \\
\text { Chinese }\end{array}$ & $\begin{array}{l}\text { No Operating } \\
\text { License }\end{array}$ \\
\hline $\begin{array}{c}\text { Gabon Xiang } \\
\text { Jiang }\end{array}$ & Sawing & Owendo & 12,000 & 1000 & ND & $\begin{array}{l}\text { No Operating } \\
\text { License }\end{array}$ \\
\hline Huajia & Sawing & Owendo & 15,381 & 780 & $\begin{array}{c}155 \text { people: } 130 \\
\text { Gabonese and } \\
25 \text { Chinese }\end{array}$ & $\begin{array}{l}\text { No Operating } \\
\text { License }\end{array}$ \\
\hline $\begin{array}{l}\text { Emirates } \\
\text { Bois SARL }\end{array}$ & Sawing & Makokou & 14,400 & 700 & ND & $\begin{array}{c}\text { No Operating } \\
\text { License }\end{array}$ \\
\hline Total & & & 96,181 & & & \\
\hline
\end{tabular}

Source: Directorate for Development of Timber Industries and Trade.

strengthening of their activities. In the first hypothesis, which seems very likely, by the effects combined the rigor of the Gabonese State in the application of the measure enforced from mid May 2010, the lack of cash flow related to export logs, but also of bad practices operated by good number of These companies (absence of development plan for most), there is concern Wild wood cuts [28]. This strategy would, for these operators, of put the Gabonese State fait accompli to get him an authorization to export of these woods as by the past. Indeed, since the announcement of the Government Bill to ban on the export of logs, November 5, 2009, the majority of operators, forest, panicking, tenfold and their timber production that led Gabon to issue exceptional authorization of export of wood until March 2010 [29]. From the perspective of stopping their activities in Gabon, these operators, like others could also transfer their assets to neighboring countries are Cameroon, the Congo and Equatorial Guinea. However, the task won't be there not easier because of the current rise in the price of the wood especially in Cameroon where are concentrated the bulk of sellers and buyers of timber from Central Africa and the West. The second hypothesis or optimistic scenario on the other hand, would be to strengthen the presence of the companies Chinese capital because of the huge interest already earned in the country. In this perspective, some of companies surveyed have indicated their intentions in the medium-term relocate some of their plants of 1st and 2nd transformation [30]. This courageous strategy will be obviously a related significant financial impact to the capacity building in facilities, equipment, technology and skills transfer for the wood not to mention implementing a logging to low impact environmental. In this sense, companies Along Sarl and Sunly-Gabon intend to increase their annual industrial capacity transformation. Just like Sunly-Gabon, which says it is ready to add additives industrial capabilities in Lambaréné. 
However, these companies have wanted more support of the Gabonese authorities through the implementation of the Support 20 billion Fund recently established by presidential decision in February 2010. Similarly, that they seek the many municipal tax exemption (production tax, taxes on property, cutting taxes, etc.) the preventing to operate optimally. Finally, they require the urgent implementation of customs exemptions decided by the Government to promote the further processing of the Gabonese wood. The Protocol said "Cooperation in forestry", signed on September 8, 2004 in Beijing (China) [31], between the Department and "load of waters and forests of the Gabonese Republic and the national development and Reform Commission the Republic of China would be an excellent framework to promote these new perspectives.

\section{Conclusion}

Chinese companies play a preponderant role in the Gabonese timber sector through the exploited and managed surfaces held, and they participate weakly in the development of the economy of this country because of the export of the majority of logs exploited and their preferential use of Chinese material and labor. However, thanks to new government measures aimed at the total ban on Gabonese log exports which took place in 2010, Chinese companies are reorganizing themselves to evolve in accordance with these new guidelines and doing their best in the win-win relationship in both countries.

\section{Acknowledgements}

This research was supported by the Fundamental Research Funds for the Central Universities (2016-JX07) and the Beijing Social Science Fund (16YJB009).

\section{References}

[1] State Forest Administration (SFA). (2010) China's Forestry Development Report. China Forestry Publishing House, Beijing.

[2] tête forestier, Jeune Afrique 12/03/2010. http://www.jeuneafrique.com/198137/archives-thematique/casse-t-te-forestier/

[3] Szirmai, A. and Verspagen, B. (2010) Is Manufacturing Still an Engine of Growth in Developing Countries? The 31 st General Conference of the International Association for Research in Income and Wealth, Switzerland. http://www.iariw.org/papers/2010/6cSzirmai.pdf

[4] Kozak, R. and Canby, K. (2007) Why China Prefers Logs: Explaining the Prevalence of Unprocessed Wood in China's Timber Imports. Forest Trends, Washington DC.

[5] Yuan, D., Fei, B., Chen, Y. and Zhang, X. (2007) The Status and Trend of International Wood-Based Panel Machinery Development. World Forestry Research, 20, 60-67.

[6] Yang, C. (2008) Corporate Social Responsibility and China's Overseas Extractive Industry Operations: Achieving Sustainable Natural Resource Extraction. Falls Church: Foundation for Environmental Security \& Sustainability (FESS).

[7] ITTO. (2009) Annual Review and Assessment of the World Timber Situation 2008. International Tropical Timber Organization, Yokohama. 
[8] ITTO. (2009) Trade Startled by Gabon Announcement. Tropical Timber Market Report, 14, 2.

[9] Adaptation Partnership. (2011) Gabon: Review of Current and Planned Adaptation Action.

[10] EU Commission, The EU, Africa and China: Towards Trilateral Dialogue and Cooperation (+ Annexes), \{SEC(2008)2641\} Brussels, 17.10.2008, COM(2008)654 Final。

[11] Canby, K., Hewitt, J., Bailey, L., Katsigris, E. and Sun, X.F. (2008) Forest Products Trade between China \& Africa, An Analysis of Imports \& Exports. Forest Trends.

[12] ITTO. (2010) Clarification on Gabon Log Ban. Tropical Timber Market Report, 15, 2.

[13] Terheggen, A. (2010) The New Kid in the Forest: The Impact of China's Resource Demand on Gabon's Tropical Timber Value Chain. Ph.D Dissertation, Open University, Milton Keynes.

[14] Nadvi, K. (2008) Global Standards, Global Governance and the Organization of Global Value Chains. Journal of Economic Geography, 8, 323-343. https://doi.org/10.1093/jeg/lbn003

[15] Lu, W. (2010) FLEGT: Opportunities and Challenges for China. The 23rd IUFRO World Congress, Seoul, 23-28 August.

[16] ITTO (2011) Status of Tropical Forest Management.

[17] Nessi Juli en (2008) Afrique, nouveau terrain de chasse. http://mascareignas.blogspot.com/2007/04/lafrique-nouveau-terrain-de-chasse-de.h $\underline{\mathrm{tml}}$

[18] Taylor, R.E., STCP Engenharia De Projectos Ltd. and Hing, L.W. (2005) Measures to Promote the Expansion and Diversification of International Trade in Tropical Timber. International Tropical Timber Organization (ITTO), Yokohama.

[19] Bosshard, P. (2008) China's Environmental Footprint in Africa. China in Africa Policy Briefing, No. 3, 1-12.

https://www.internationalrivers.org/sites/default/files/attached-files/saiia_policy_bri efing_508.pdf

[20] World Bank (2008) Project Information Document (PID) Concept Stage. Report No. AB3601, The World Bank, Washington DC.

http://documents.worldbank.org/curated/en/882741468030314152/Project0Inform1 cument1Concept0Stage.doc

[21] Lawson, S. (2010) Illegal Logging and Related Trade: Indicators of the Global Response. Chatham House Briefing Paper 2010 No. 2, Royal Institute of International Affairs, London.

https://www.chathamhouse.org/sites/files/chathamhouse/public/Research/Energy,\% 20Environment\%20and\%20Development/0710bp_illegallogging.pdf

[22] Broadman, H.G. (2007) Africa's Silk Road: China and India's New Economic Frontier. The World Bank, Washington DC.

https://books.google.com/books?hl=fr\&lr=\&id=fkBJ0HL34WsC\&oi=fnd\&pg=PR5\& dq=\%5B22\%5D\%09Broadman, + H.+G.+(2007).+Africa\%E2\%80\%99s+silk+road:+C hi-

na+and+India\%E2\%80\%99s+new+economic+frontier.+Washington,+DC:+The+W orld+Bank.\&ots=uevAbZyeuK\&sig=gFCouXk-NtGr--He4EuCmmdHTXk\#v=onepa ge\&q\&f=false

[23] Sanfilippo, M. (2010) Chinese FOI to Africa: What Is the Nexus with Foreign Eco- 
nomie Cooperation? Africa Development Review, 22, 599-614.

https://onlinelibrary.wiley.com/doi/full/10.1111/j.1467-8268.2010.00261.x

[24] (2010) Republic of Gabon, Support to Sustainable Forest Resource Management in Gabon. African Development Bank.

https://www.afdb.org/fileadmin/uploads/afdb/Documents/Policy-Documents/Gabo n_-_APRVD_FFBC_Project_eng.pdf

[25] Bridge, G. (2008) Global Production Networks and the Extractive Sector: Governing Resource-Based Development. Journal of Economic Geography, 8, 389-419.

https://doi.org/10.1093/jeg/lbn009

https://academic.oup.com/joeg/article-abstract/8/3/389/943089

[26] Republique Gabonaise. Stratégie Nationale d'Industrialisation. Ministère des Mines. http://www.mines.gouv.ga/object.getObject.do?id=1148

[27] Obiorah, N. (2007) Who's Afraid of China in Africa? In: Manji and Marks, Eds., African Perspectives on China in Africa, Pambazuka Books, London, 35-56.

[28] Asche, H. and Schuller, M. (2008) China's Engagement in Africa-Opportunities and Risks for Development. Deutsche Gesellschaft fur Technische Zusammenarbeit (GTZ) GmbH, Eschborn.

[29] OECD (2009) African Economic Outlook 2009: Country Profile Gabon. Organisation for Economic Cooperation and Development, Paris. https://doi.org/10.1787/aeo-2009-en

[30] Alves, A.C. (2008) China and Gabon: A Growing Resource Partnership. The South African Institute of International Affairs (SAIIA), Braamfontein.

[31] Corkin, L., Burke, C. and Davies, M. (2008) China's Role in the Development of Africa's Infrastructure. Working Papers in African Studies 04-08, SAIS Johns Hopking University, $21 \mathrm{p}$. 